\title{
Perancangan dan Pembuatan Aplikasi Pembelajaran Bahasa Jepang Untuk Pemula Dengan Metode User Centered Design Berbasis Android
}

\author{
Michael Agustav \\ Program Studi Teknik Informatika \\ Institut Informatika Indonesia \\ kielmax26@gmail.com
}

\author{
Kathryn Widhiyanti \\ Program Studi Sistem Informasi \\ Institut Informatika Indonesia \\ kathryn@ikado.ac.id
}

\author{
Edwin Meinardi Trianto \\ Program Studi Teknik Informatika \\ Institut Informatika Indonesia \\ edwin@ikado.ac.id
}

\begin{abstract}
Abstrak - Seiring perkembangan zaman dimana perdagangan bebas Asia Pasifik mulai sering terjadi, maka penduduk Indonesia perlu mempelajari bahasa lain selain bahasa Indonesia. Bahasa Jepang perlu dipelajari karena mulai banyak investor asing dari negara Jepang di Indonesia. Oleh sebab itu dibuat aplikasi sederhana untuk membantu proses pembelajaran bahasa Jepang untuk pemula menggunakan metode User Centered Design. Dalam metode User Centered Design pada pembuatan aplikasi pembelajaran aplikasi pembelajaran bahasa Jepang untuk pemula ini dilakukan dengan membuat prototype pertama berupa hand-sketches prototype, kemudian dibuat prototype kedua berupa realisasi dari hasil handsketches, dan yang terakhir dibuat prototype ketiga berupa dynamic design prototype. Dari ketiga jenis prototype juga dilengkapi dengan evaluasi terhadap pengguna dan dilakukan perbaikan. Kemudian untuk pengujian telah dilakukan dua kali pengujian menggunakan metode dari usability testing yaitu completing a transaction dan evaluating the impact of subtle changes. Hasil dari kedua pengujian itu telah dianalisa dan dihitung, berdasarkan hasil analisa tersebut disimpulkan bahwa pada pengujian completing a transaction mendapatkan hasil $\mathbf{9 2 , 3 \%}$ menunjukkan bahwa pengguna telah memahami fitur dan fungsi dari tombol yang telah disediakan pada aplikasi pembelajaran bahasa Jepang yang telah dibuat dan pada hasil pengujian evaluating the impact of subtle changes mendapatkan hasil $100 \%$ hasil tersebut menunjukkan bahwa pengguna telah dapat mempelajari bahasa Jepang dengan menggunakan aplikasi pembelajaran bahasa Jepang yang dibuat.

Kata Kunci: Android, Bahasa Jepang, User Centered Design, Usability Testing, Starling, Action Script 3, Adobe Flash Builder
\end{abstract}

\section{PENDAHULUAN}

Pada zaman sekarang dimasa perdagangan bebas Asia Pasifik mulai sering terjadi, maka penduduk Indonesia perlu mempelajari bahasa lain selain bahasa Indonesia. Seperti bahasa Inggris, bahasa Cina, bahasa Jepang, dan lain-lain.

Oleh sebab itu perlu adanya pembelajaran bahasa asing untuk memudahkan proses perdagangan supaya mempermudah dalam hal berkomunikasi, di Indonesia sudah mulai banyak investor dari negara Jepang. Oleh sebab itu penulis membuat aplikasi pembelajaran bahasa Jepang untuk pemula.

Seiring dengan perkembangan teknologi yang semakin maju dengan banyaknya penggunaan android, maka penulis membuat aplikasi pembelajaran bahasa Jepang untuk pemula ini berbasis android, supaya pembelajaran yang diajarkan dapat dilakukan dimana saja dan kapan saja demi meningkatkan keefisiensian dari aplikasi tersebut.

Bahasa Jepang (Nihon-go) sendiri dibagi menjadi 5 level dengan tingkat kemahiran yang berbeda. 5 level tersebut ditentukan dengan test JLPT (Japanese Language Proficiency Test) yang diadakan tiap tahunnya di Indonesia. Level yang diujikan pun berbeda berdasarkan kemampuan yang telah dipelajari dimulai dari N5 dengan tingkat kesulitan paling rendah sampai N1 dengan tingkat kesulitan paling tinggi.

Pada aplikasi yang dibuat nantinya pembelajaran bahasa Jepang yang diajarkan adalah bahasa Jepang untuk tingkat pemula dengan level paling dasar setara dengan N5 (nihonggo nouryokushiken 5).

Metode pembelajaran yang dilakukan adalah pengenalan bahasa Jepang dasar terlebih dahulu, diawali dengan pembelajaran huruf vokal (a, i, u, e, o). Kemudian menggunakan huruf vokal tersebut nantinya dilanjutkan dengan pembelajaran huruf konsonan, kemudian dilanjutkan pembelajaran dengan menggabungkan huruf vokal dan huruf konsonan menjadi sebuah kata. Nantinya kata-kata yang dipelajari digabungkan menjadi kalimat sederhana. 


\section{METODOLOGI PENELITIAN}

\section{A. Hiragana}

Hiragana sendiri mempunyai 46 karakter yang mewakili 46 bunyi yang berbeda. Dalam pemakaiannya, Hiragana dipakai untuk menyatakan elemen tata bahasa seperti partikel dan akhiran kata sifat dan kata kerja yang menunjukkan tatabahasa.

Hiragana adalah salah satu daripada tiga cara penulisan dalam bahasa Jepang. Hiragana adalah salah satu cara penulisan bahasa jepang yang mewakili sebutan suku kata. Pada masa silam, ia juga dikenali sebagai "Onna de" atau "tulisan wanita" karena biasa digunakan oleh kaum wanita. Kaum lelaki pada masa itu menulis menggunakan tulisan Kanji dan Katakana.

\section{B. User Centered Design (UCD)}

Konsep dari UCD adalah user sebagai pusat dari proses pengembangan sistem, dan tujuan/sifat-sifat, konteks dan lingkungan sistem semua didasarkan dari pengalaman pengguna. Dalam UCD, partisipasi dan pengalaman manusia dalam proses perancangan merupakan prioritas utama. Pengguna langsung atau biasa disebut pengguna akhir (end user) merupakan orang yang akan menggunakan sistem untuk menyelesaikan pekerjaannya. Sedangkan pengguna tidak langsung adalah pengguna yang menggunakan sistem untuk penggunaan yang lain seperti sistem administrators, installers, dan demonstrators. Prinsip-prinsip dalam merancang user interface adalah sebagai berikut [1]:

1. User familiarity/mudah dikenali: menggunakan istilah yang lazim digunakan dan dikenali oleh pengguna secara umum, misalnya: untuk sistem perkantoran gunakan istilah letters, documents, folders bukan directories, file, identifiers.

2. Consistency: Konsisten dalam operasi dan istilah yang digunakan di seluruh sistem sehingga tidak membingungkan.

3. Minimal surprise/tidak membuat pengguna terkejut: Operasi yang terjadi dapat diprediksi oleh pengguna sesuai dengan perintah yang ada.

4. Recoverability/pemulihan: Recoverability ada dua macam yaitu: confirmation of destructive action (konfirmasi terhadap aksi yang merusak) atau ketersediaan fasilitas pembatalan (undo).

5. User guidance/bantuan: Adanya cara penggunaan sistem sehingga pengguan lebih mudah dalam menjalankan sistem.

Prinsip perancangan UCD dapat digambarkan seperti pada gambar dibawah ini.

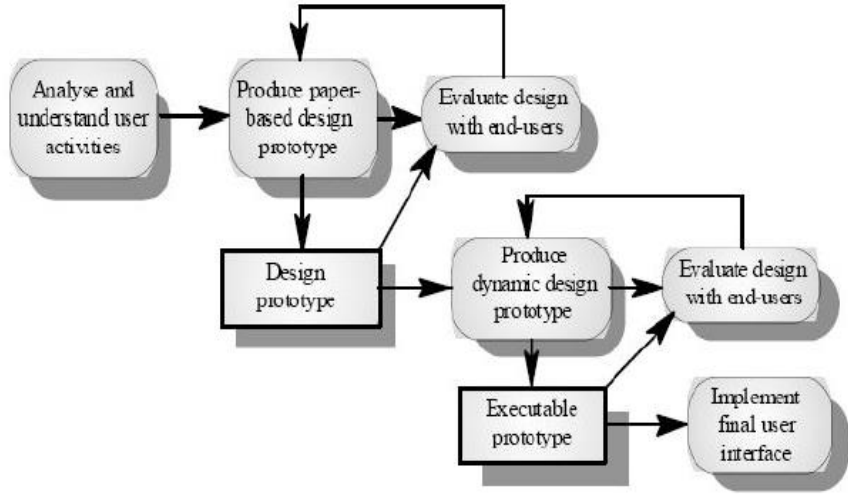

Gambar 1. Prinsip Perancangan UCD.

\section{Starling}

Starling adalah ActionScript 3 Library untuk Adobe Flash. Ini dapat membuat kembali tambilan Adobe Flash pada GPU dan memberikan performa yang luar biasa bahkan pada platform mobile, seperti iOS dan Android.

Selain bahasa, Starling ini tidak memerlukan pengetahuan tentang dasar Flash (ActionScript 3). Starling memulai penjelasan dari awal, dimulai dengan cara mengatur proyek, kemudian menjelaskan bagaimana pohon display dan sistem event bekerja, dan menunjukkan kepada anda bagaimana untuk mencapai tugas-tugas tertentu, seperti menghidupkan benda.

\section{Android SDK}

Android SDK merupakan sebuah tools yang diperlukan untuk mengembangkan aplikasi berbasis Android menggunakan bahasa pemrograman Java. Reito Meiler mengingatkan "Pada saat ini Android SDK telah menjadi alat bantu dan API (Application Programming Interface) untuk mengembangkan aplikasi bebasis Android"'[2]. Android SDK dapat Anda lihat dan unduh pada situs resminya, yaitu http://www.developer.android.com/. Android SDK bersifat gratis dan bebas Anda distribusikan karena Android bersifat open source.

Android SDK telah dirilis pada tanggal 12 November 2007. Dan pada tanggal 15 Juli 2008 tim Android Developer Challenge sengaja mengirimkan email ke semua pendatang di Android Developer Challenge untuk mengumumkan bahwa rilis SDK terbaru telah tersedia pada halaman download.

\section{E. Aplikasi Pembelajaran}

Belajar adalah perubahan yang relatif permanen dalam perilaku atau potensi perilaku sebagai hasil dari pengalaman atau latihan yang diperkuat. Belajar merupakan akibat adanya interaksi antara stimulus dan respon [3]. Aplikasi adalah perangkat lunak yang memanfaatkan kemampuan komputer langsung untuk melakukan suatu tugas yang diinginkan pengguna. Aplikasi pembelajaran adalah perangkat lunak yang digunakan untuk mendapatkan informasi yang belum diketahui sebelumnya. Aplikasi pembelajaran biasanya dibuat dalam bentuk permainan 


\section{HASIL DAN PEMBAHASAN}

Sebelum dilakukan implementasi program, perlu dilakukan analisa dan desain sistem untuk mempermudah implementasi program sebagai acuan untuk menghasilkan program yang baik.

\section{A. Analisa Pengguna}

Pembuatan aplikasi pembelajaran bahasa Jepang untuk pemula ini didasari dengan konsep yang disesuaikan dengan kebutuhan pengguna, pengguna yang memberikan kebutuhan disini terdiri dari 3 orang dengan kemampuan pemahaman berbahasa Jepang yang berbeda-beda, ketiga pengguna ini menjadi nara sumber yang membantu dalam hal pembuatan desain antarmuka awal dan sebagai narasumber data pembelajaran apa saja yang nantinya akan diberikan pada aplikasi pembelajaran bahasa Jepang untuk pemula ini. Berikut adalah kriteria dari ketiga pengguna narasumber utama :

- Pengguna dengan kemampuan berbahasa Jepang fasih, yaitu Aiko (25). Seorang pelajar bahasa Indonesia untuk orang asing (berkewarganegaraan Jepang asli) di Indonesia. Dipilih menjadi pengguna supaya dapat digunakan untuk membandingkan kemampuan belajar bahasa Jepang untuk pemula di Indonesia, memberikan sumber data apa saja dalam hiragana yang perlu dimasukkan dalam proses pembelajaran.

- Pengguna dengan kemampuan berbahasa Jepang menengah, yaitu Dimas (28). Seorang teknisi IT disebuah perusahaan Jepang di Indonesia. Dipilih menjadi pengguna karena beliau mengerti dan pernah melewati proses pembelajaran mulai dari awal.

- Pengguna yang tidak memiliki kemampuan berbahasa Jepang, yaitu Riandy (18). Seorang pelajar sebuah SMA. Dipilih menjadi pengguna dengan tujuan aplikasi pembelajaran ini dapat diujikan kepada beliau sebelum dipublikasikan ke masyarakat luas.

\section{B. Analisa Kebutuhan Aplikasi}

Berdasarkan hasil wawancara terhadap ketiga pengguna sebagai narasumber utama dan diskusi dengan 12 pengguna yang telah dilakukan sebelumnya dapat disimpulkan bahwa dalam aplikasi pembelajaran bahasa Jepang untuk pemula ini, nantinya akan mengajarkan bahasa Jepang dari awal, bahasa Jepang yang mengenalkan kepada pengguna sebelum pengguna nantinya masuk ke level N5 secara penuh. Bahasa Jepang yang dikenalkan nantinya akan dibagi menjadi 3 level berdasarkan tingkat kemudahannya.

Tabel 1. Tabel Pembagian Bahasa Jepang Pada Bagian Pembelajaran.

\begin{tabular}{ccl}
\hline No & Level & \multicolumn{1}{c}{ Pembelajaran } \\
\hline 1. & Level 1 & Pengenalan huruf vokal dan konsonan. \\
\hline 2. & Level 2 & $\begin{array}{l}\text { Penggabungan huruf vokal dan } \\
\text { konsonan menjadi kata - kata sederhana. }\end{array}$ \\
\hline 3. & Level 3 & $\begin{array}{l}\text { Penggabungan kata-kata sederhana } \\
\text { menjadi sebuah kalimat sederhana. }\end{array}$ \\
\hline
\end{tabular}

Dari 3 level pembelajaran yang telah diberikan, masingmasing dari level tersebut juga dilengkapi dengan kuis. Pada bagian kuis ini dilengkapi dengan 2 pilihan yaitu mudah dan sulit, pilihan tersebut menentukan berapa jumlah soal yang akan didapat pada sesi tersebut (mudah 10 soal \& sulit 15 soal). Masing-masing kuis dilengkapi dengan 2 pilihan jawaban dari masing-masing pertanyaan yang diberikan. Kuis yang diberikan berhubungan dengan proses pembelajaran yang telah dilewati. Kuis tersebut dilengkapi dengan skor dengan bobot penilaian berbeda-beda dari tiap level kuis yang dihadapi, kuis pada level 1 akan terbuka secara bersamaan dengan bagian pembelajaran pada level 1 .

Pada kuis level 1 skor yang didapatkan oleh pengguna apabila menjawab pertanyaan dengan benar adalah 10 poin, dari poin tersebut pengguna harus mengumpulkan skor minimal 70 poin untuk membuka kuis pada level 2, begitu pula dengan kuis pada level 3 pengguna harus mengumpulkan minimal 105 poin dari kuis pada level 2. Pada level 2 skor yang didapat oleh pengguna setiap kali memberikan jawaban benar adalah 15 poin dan pada bagian kuis level 3 poin yang didapatkan pengguna adalah 20 poin dari setiap soal yang telah diberikan. Berikut adalah pembagian skor pada bagian kuis dalam bentuk tabel:

Tabel 2. Tabel Pembagian Skor.

\begin{tabular}{cccccc}
\hline No & Level & $\begin{array}{c}\text { Skor } \\
\text { Jawaban }\end{array}$ & $\begin{array}{c}\text { Skor } \\
\text { Min. }\end{array}$ & $\begin{array}{c}\text { Skor } \\
\text { Maks. } \\
\text { (Mudah) }\end{array}$ & $\begin{array}{c}\text { Skor } \\
\text { Maks. } \\
\text { (Sulit) }\end{array}$ \\
\hline 1. & $\begin{array}{c}\text { Level } \\
1\end{array}$ & 10 & 70 & 100 & 150 \\
\hline 2. & $\begin{array}{c}\text { Level } \\
2\end{array}$ & 15 & 105 & 150 & 225 \\
\hline 3. & $\begin{array}{c}\text { Level } \\
3\end{array}$ & 20 & - & 200 & 300 \\
\hline
\end{tabular}

\section{Use Case Diagram}

Use Case Diagram menjelaskan urutan kegiatan yang dilakukan aktor dan sistem untuk mencapai tujuan tertentu. Dalam pembuatan aplikasi pembelajaran bahasa Jepang untuk pemula ini juga telah dibuat use case diagram yang menjelaskan apa saja yang nantinya akan dilakukan oleh aktor (pengguna) terhadap sistem. Berikut ini adalah use case diagram dari aplikasi pembelajaran bahasa Jepang untuk pemula seperti terlihat dalam gambar 2 .

Pada gambar 2. aktor memilih menu mulai, kemudian program akan menampilkan pilihan level dan pengguna akan memilih level yang akan dipelajari. Pada masing-masing level dibagi menjadi 2 bagian, yaitu bagian pembelajaran dan bagian kuis. Bagian pembelajaran terbuka untuk semua level, sedangkan untuk bagian kuis pada awal aplikasi hanya terbuka bagian kuis pada level 1 saja, kemudian setelah menyelesaikan kuis pada level 1 aktor akan mendapatkan skor. Dari skor tersebut nantinya akan digunakan untuk membuka bagian kuis pada level selanjutnya. 


\section{Activity Diagram}

Activity diagram adalah representasi grafis dari seluruh tahapan alur kerja. Diagram ini mengandung aktivitas, pilihan tindakan, perulangan dan hasil dari aktivitas. Activity diagram tidak menggambarkan behavior internal sebuah sistem (dan interaksi antar subsistem) secara eksak, tetapi lebih menggambarkan proses-proses dan jalur-jalur aktivitas dari level atas secara umum. Activity diagram juga dapat menggambarkan proses paralel yang mungkin terjadi pada beberapa eksekusi. Activity diagram dibuat berdasarkan sebuah atau beberapa use case pada use case diagram [4]. Berikut activity diagram yang terdapat pada aplikasi pembelajaran bahasa Jepang untuk pemula seperti terlihat dalam gambar 3 .

Pada gambar 3, activity diagram akan menjelaskan hubungan pengguna dengan proses jalannya aplikasi. Pada awalnya pengguna menjalankan sistem aplikasi pembelajaran bahasa Jepang untuk pemula, kemudian sistem akan menampilkan menu mulai, kemudian pengguna diharapkan memilih menu mulai supaya sistem dapat melanjutkan ke bagian level.

Setelah sistem menampilkan menu mulai pengguna diminta untuk memilih level yang akan dipilih. Setelah pengguna memilih level yang sesuai sistem akan menampilkan bagian pembelajaran dan kuis sesuai dengan level yang telah dipilih oleh pengguna. Selanjutnya apabila pengguna memilih menu pembelajaran, maka sistem akan menampilkan bagian pembelajaran sesuai dengan level yang telah dipilih sebelumnya, apabila pengguna memilih menu kuis maka sistem akan mengecek apakah sebelumnya sudah ada skor tersimpan atau belum.

Apabila belum ada skor tersimpan maka bagian kuis yang terbuka adalah bagian kuis level 1. Selanjutnya apabila sistem telah menyimpan skor yang cukup untuk membuka bagian kuis pada level berikutnya, maka sistem akan mengijinkan pengguna untuk mengakses bagian kuis pada level selanjutnya yang dapat diakses melalui bagian menu pilihan level terlebih dulu. Pada bagian kuis sebelum masuk ke bagian pertanyaan dan pilihan jawaban pengguna diberikan pilihan menu berupa "mudah" dan "sulit" pilihan tersebut digunakan untuk menentukan jumlah soal yang akan dikeluarkan pada bagian kuis yang telah dipilih.

Apabila pengguna telah menjawab pertanyaan kuis pada level yang telah dipilih, maka sistem akan mengecek apakah pertanyaan yang diberikan telah mencapai pertanyaan terakhir dari jumlah pertanyaan yang telah dipilih untuk diselesaikan pada bagian menu mudah dan sulit sebelumnya maka sistem akan menampilkan halaman skor dan menampilkan skor yang telah didapat. Setelah pembuatan activity dan use case diagram maka proses selanjutnya adalah pembuatan desain prototype dari aplikasi pembelajaran bahasa Jepang untuk pemula.

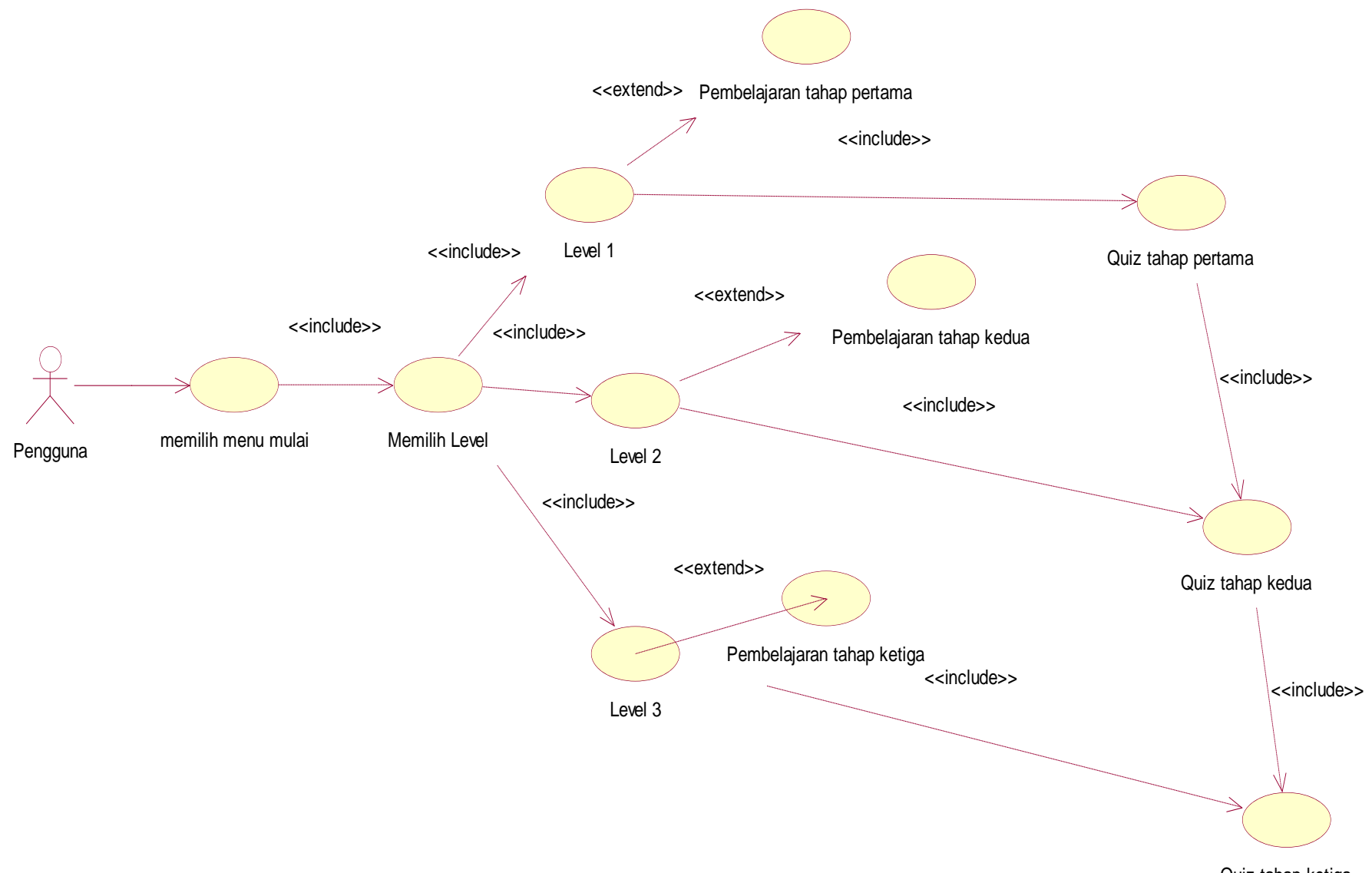

Gambar 2. Use Case Diagram Aplikasi Pembelajaran Bahasa Jepang Untuk Pemula. 


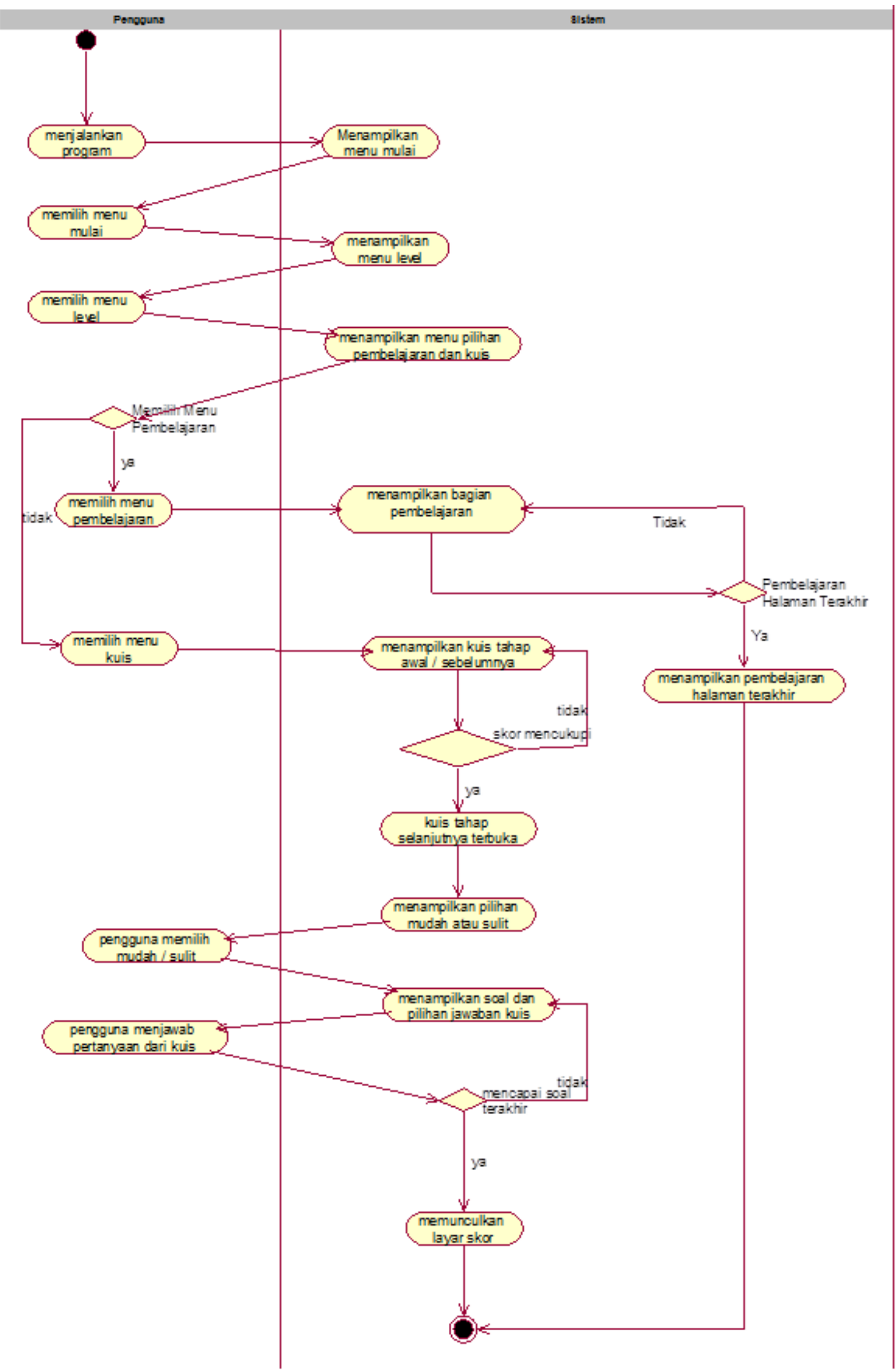

Gambar 3. Activity Diagram Aplikasi Pembelajaran Bahasa Jepang Untuk Pemula. 
E. Desain Prototype Pertama (Hand-Sketches Prototype)

Pada $s u b$-bab ini penulis akan merealisasikan kebutuhan ketiga narasumber utama menjadi sebuah prototype desain awal, desain prototype awal ini nantinya akan diujikan lagi kepada kedua belas pengguna yang telah ditentukan apakah desain sudah sesuai dengan kebutuhan pengguna atau tidak.

\section{a. Prototype Desain Menu Awal}

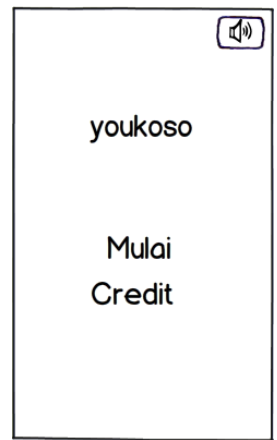

Gambar 4. Prototype Desain Menu Awal

Pada gambar 4 ini berisi menu awal ini yang berisi tombol mulai yang berguna untuk memulai proses pembelajaran maupun kuis, tombol credit yang berisi informasi mengenai tim pembuat aplikasi pembelajaran bahasa Jepang untuk pemula ini. Serta tombol V yaitu tombol volume yang berisi pengaturan latar belakang musik dan efek suara.

b. Desain Menu Pilihan Level

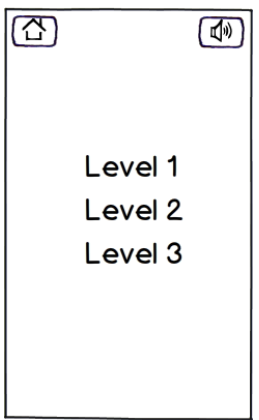

Gambar 5. Prototype Desain Menu Pilihan Level

Pada gambar 5 ini pengguna ditunjukkan menu pilihan level yang menjadikan perbedaan proses pembelajaran maupun kuis menjadi berbeda dibagi dengan tingkat kemudahannya, tingkat tersebut dibagi menjadi 3 berdasarkan kemudahan pembelajaran yang diberikan. Pada level 1 pembelajaran yang diberikan adalah pembelajaran mengenal aksara hiragana dari huruf vokal dan konsonan, pada level 2 pembelajaran yang diberikan adalah penggabungan huruf vokal dan huruf konsonan menjadi sebuah kata sederhana, kemudian pada level 3 pembelajaran yang diberikan adalah pengenalan kalimat sederhana yang sering digunakan sehari-hari.

c. Desain Bagian Pembelajaran

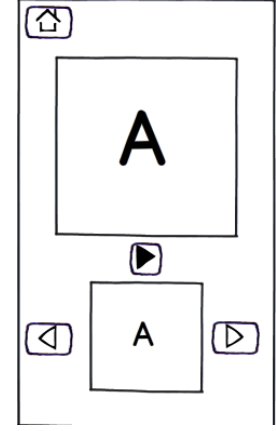

Gambar 6. Prototype Desain Pembelajaran

Pada gambar 6 ini pengguna disuguhkan dengan proses pembelajaran dari hiragana dasar dari tiap-tiap levelnya. Dari tiap bagian pembelajaran dilengkapi dengan penulisan hiragana, tombol yang mengeluarkan pelafalan dari masingmasing huruf hiragana yang ditunjukkan, serta dilengkapi dengan romaji dari masing-masing pembelajaran, maupun arti kata dari masing-masing huruf hiragana yang ditunjukkan.

\section{d. Desain Bagian Kuis}

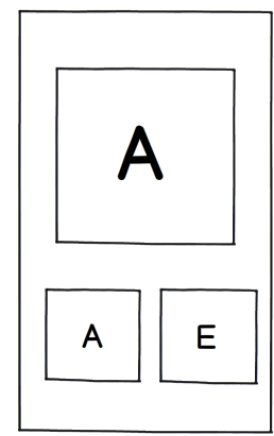

Gambar 7. Prototype Desain Kuis

Pada gambar 7 ini pengguna disuguhkan dengan bagian kuis. Bagian kuis dilengkapi dengan 2 pilihan jawaban, dan dilengkapi dengan soal yang diberikan sesuai dengan level kuis yang sedang dijalankan.

\section{e. Evaluasi Desain Prototype Pertama (Hand-Sketches Prototype)}

Dari prototype tahap pertama di atas dipaparkan kepada ketiga pengguna nara sumber utama dan dilakukan proses wawancara. Dari wawancara tersebut menghasilkan bahwa pengguna memerlukan adanya realisasi tahap awal dari prototype yang telah diberikan. maka prototype tahap pertama di atas dinyatakan sudah bisa dibuat dalam bentuk desain prototype lanjutan. Kemudian dilakukan diskusi dengan kedua belas orang berikutnya yang menjadi nara sumber dengan topik yang sama dalam diskusi tersebut penulis juga melakukan pemaparan desain kepada kedua orang nara sumber tersebut, desain, akan tetapi kepada kedua belas pengguna tersebut terdapat sebuah perbedaan dimana kepada kedua belas pengguna tersebut diberikan pertanyaan seputar Android yang digunakan. 


\section{F. Desain Prototype Kedua}

Dari tahap user centered design pertama dipaparkan kembali ke pengguna, ketiga pengguna memberikan komentar dan mengutarakan kebutuhan supaya desain antarmuka diperbaiki. Oleh karena itu dibuat sebuah prototype lanjutan berupa desain nyata dari hand-sketches. Berikut adalah perbaikan dari desain prototype awal :

a. Prototype Desain Menu Awal

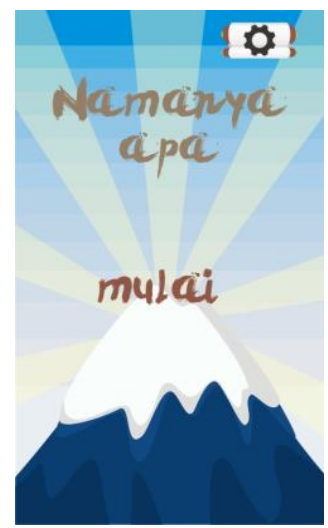

Gambar 8. Prototype Desain Menu Awal.

Pada gambar 8 ini merupakan prototype tahap kedua dari menu awal, pada tahap ini menu awal sudah tidak memiliki menu pilihan credit lagi. Tombol credit dimasukkan kedalam tombol setting, tombol setting di pojok kanan atas berisi seperti pada gambar berikut:

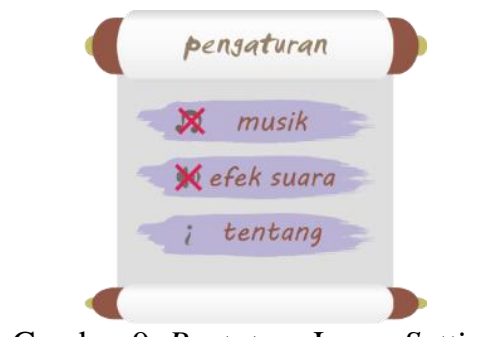

Gambar 9. Prototype Layar Setting

Pada gambar 9 merupakan prototype dari layar setting contoh yang diberikan apabila musik latar dan efek suara dimatikan maka icon pada tombol musik dan efek suara memiliki tanda silang. Tombol tentang merupakan pengganti dari tombol credit pada menu awal yang telah dipaparkan pada prototype tahap pertama.

b. Desain Menu Pilihan Level

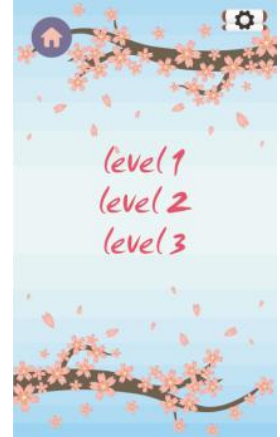

Gambar 10. Prototype Desain Menu Pilihan Level.

Pada gambar 10 ini tidak terjadi banyak perubahan dari prototype pada tahap pertama yang telah dipaparkan sebelumnya. Pada prototype tahapa kedua ini dapat dilihat terdapat penambahan tombol home pada ujung kiri atas yang apabila ditekan layar akan kembali ke menu utama.

c. Desain Menu Pilihan Pembelajaran dan Kuis

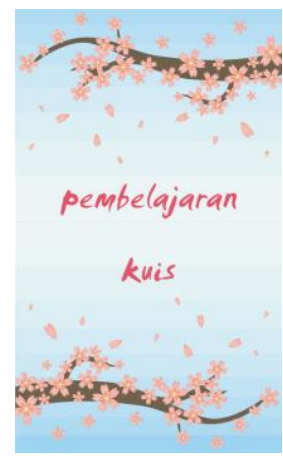

Gambar 11. Prototype Desain Menu Pilihan Pembelajaran dan Kuis.

Pada gambar 11 merupakan layar yang keluar ketika salah satu tombol level ditekan. Layar akan menunjukkan 2 tombol yaitu tombol yaitu tombol pembelajaran dan tombol kuis, tombol pembelajaran apabila ditekan layar pada aplikasi akan menujukkan layar bagian pembelajaran sesuai level yang dipilih. Begitu pula dengan tombol kuis, apabila ditekan akan mengarahkan pengguna ke bagian kuis sesuai dengan level yang dipilih.

d. Desain Menu Level Kuis

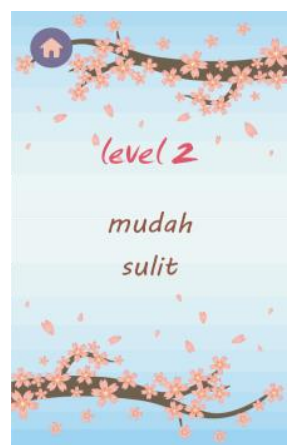

Gambar 12. Prototype Desain Menu Level Kuis 
Pada gambar 12 merupakan layar yang ditampilkan apabila tombol kuis telah dipilih. Di layar ini terdapat 3 tombol yaitu tombol home di pojok atas kiri yag berfungsi untuk kembali ke menu pembelajaran atau kuis, tombol mudah dan tombol sulit. Tombol mudah dan sulit ini sendiri digunakan untuk menentukan jumlah soal yang keluar dari kuis pada level tersebut.

\section{f. Evaluasi Desain Prototype Kedua}

Dari prototype tahap kedua yang telah dibuat di atas kemudian diujikan lagi kepada ketiga pengguna narasumber utama dengan menggunakan metode wawancara, setelah wawancara dilakukan pengguna menyarankan untuk melakukan beberapa perbaikan berupa :

1. Latar belakang menu awal terlalu mencolok

2. Pada bagian menu level tidak perlu ada tombol setting

3. Pada bagian menu pembelajaran dan kuis perlu ditambahkan penanda level berapa yang sedang dibuka. Dan perlu diberikan penanda perbedaan tombol dan tulisan.

Pada tahap ini tidak dilakukan diskusi dengan kedua belas pengguna yang telah ditentukan, akan tetapi pada tahap prototype ketiga baru dilakukan diskusi lanjutan mengenai desain yang telah dibuat dalam bentuk desain jadi beserta perbaikan pada tahap ini.

g. Perbaikan Desain Prototype Kedua

Dari 3 perbaikan di atas dapat diperbaiki sebagai berikut :

- Perbaikan Pada Latar Belakang Menu Awal

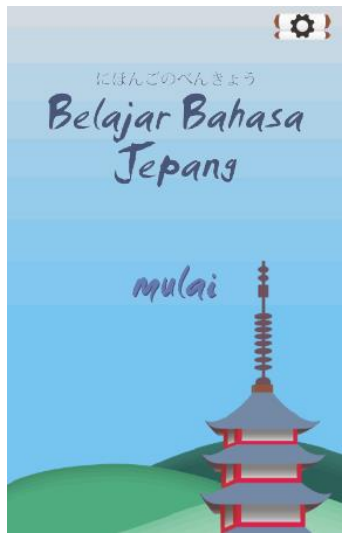

Gambar 13. Perbaikan Pada Latar Belakang Menu Awal

Dari gambar 13. di atas telah disetujui untuk latar belakang dan penggunaan judul untuk aplikasi pembelajaran bahasa Jepang untuk pemula ini menggunakan judul "Belajar Bahasa Jepang". Di atasnya terdapat tulisan dalam hiragana yaitu“にほんごのべんきょう”(nihongo no benkyou) yang artinya belajar bahasa Jepang.

- Perbaikan Pada Tombol Setting di Bagian Menu Level

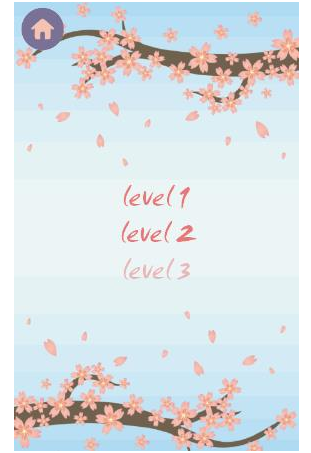

Gambar 14. Perbaikan Pada Tombol Setting di Bagian Menu Level

Pada gambar 1 di atas telah diperbaiki sesuai dengan permintaan pengguna. Permintaan pengguna pada bagian ini adalah tidak diperlukannya tombol setting pada halaman menu level oleh sebab itu tombol setting pada halaman menu level telah dihilangkan.

- Penambahan Tulisan Penunjuk Level dan Pembeda Tombol dan Tulisan

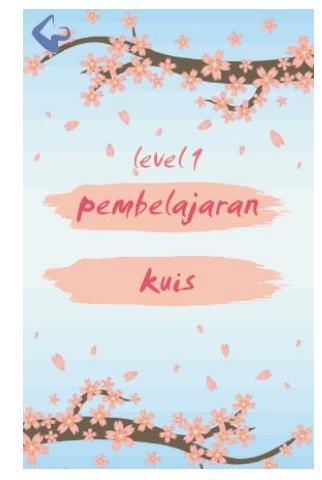

Gambar 15. Penambahan Tulisan Penunjuk Level dan Pembeda Tombol dan Tulisan.

Pada gambar 15 ini menunjukkan perbaikan desain sesuai dengan permintaan pengguna yaitu penambahan penunjuk level yang sedang dibuka dan diberikan pembeda antara tombol dan teks. Oleh sebab itu telah ditambahkan teks penunjuk level yang sedang dibuka dan penambahan warna latar pada bagian belakang tombol untuk membedakan teks dan tombol.

h. Evaluasi Perbaikan Desain Prototype Kedua

Setelah dilakukan proses perbaikan dari prototype tahap kedua tadi maka desain prototype kedua diujikan lagi kepada ketiga nara sumber utama apakah perbaikan yang telah dilakukan telah sesuai dengan permintaan ketiga pengguna tersebut. Setelah desain prototype kedua diujikan, maka dapat disimpulkan bahwa ketiga pengguna telah menyetujui untuk desain prototype yang telah diperbaiki untuk dilanjutkan menjadi prototype tahap ketiga (dynamic design prototype). 
G. Desain Prototype Ketiga (Dynamic Design Prototype)

Dari tahap user centered design kedua dipaparkan kembali ke pengguna, ketiga pengguna memberikan komentar dan kebutuhan supaya desain antarmuka diperbaiki. Berikut adalah prototype tahap ketiga (dynamic design prototype):

a. Prototype Desain Menu Awal

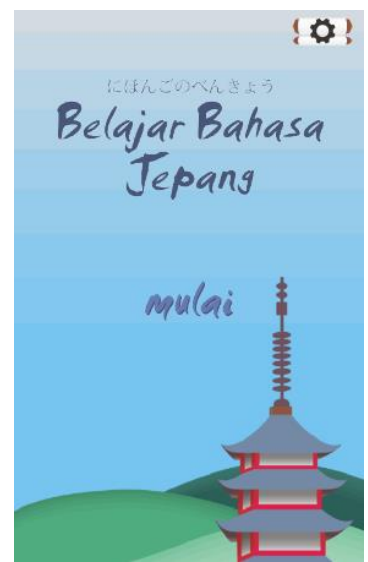

Gambar 16. Prototype Desain Menu Awal

Pada gambar 16 adalah menu awal dari aplikasi pembelajaran bahasa Jepang untuk pemula yang telah sebelumnya diperbaiki sesuai dengan kebutuhan pengguna. Pada menu ini terdapat 2 buah tombol yaitu tombol mulai dan tombol setting, tombol mulai digunakan untuk masuk kedalam bagian menu pemilihan level yang akan dipilih oleh pengguna. Sedangkan tombol setting nantinya akan mengarah kebagian setting. Pada halaman ini juga terdapat musik latar yang merupakan rekomendasi dari salah satu nara sumber, musik latar yang direkomendasikan tersebut kemudian digunakan pada aplikasi pembelajaran bahasa Jepang untuk pemula ini. Background music tersebut mulai dimainkan ketika layar telah berganti ke halaman menu utama ini.

\section{b. Prototype Desain Menu Level}

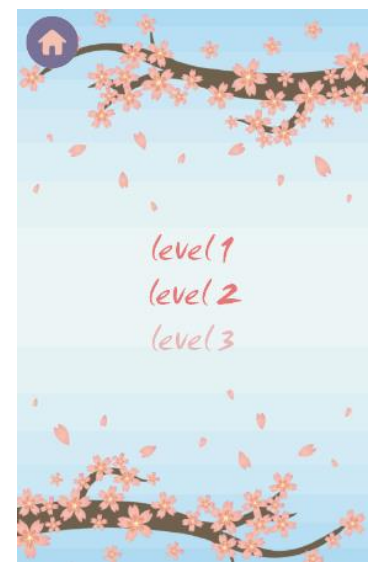

Gambar 17. Prototype Desain Menu Level
Pada gambar 17 merupakan bagian menu pilihan level yang nantinya akan dipilih oleh pengguna sesuai keinginan. Pada bagian ini terdapat 4 tombol, 3 tombol untuk bagian level dan 1 tombol home yang bisa digunakan untuk kembali ke layar sebelumnya (menu utama), pada bagian halaman ini background music pada menu utama masih dimainkan.

\section{c. Prototype Desain Menu Pembelajaran dan Kuis}

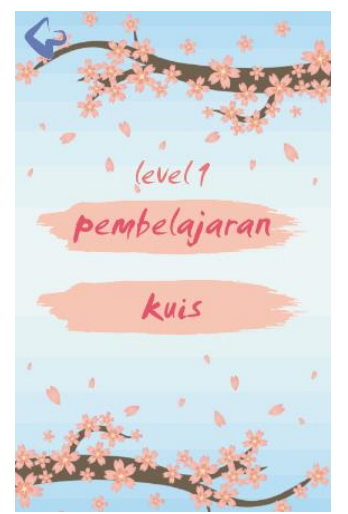

Gambar 18. Prototype Desain Menu Pembelajaran dan Kuis

Pada gambar 18 adalah lanjutan dari menu pilihan level. Apabila salah satu level dipilih maka layar akan menampilkan bagian yang ditunjukkan pada gambar 18 . pada bagian ini terdapat 3 tombol, yaitu tombol kembali yang terletak di ujung kiri atas digunakan untuk kembali ke layar pilihan level, tombol pembelajaran digunakan untuk masuk ke bagian pembelajaran, dan tombol kuis yang digunakan untuk masuk ke bagian kuis. Pada bagian halaman ini pengguna juga masih bisa mendengarkan background music halaman ini merupakan halaman terakhir background music dimainkan. Pada halaman ini tombol yang tersedia menggunakan jenis font MV Boli.

\section{d. Prototype Desain Bagian Pembelajaran Level 1}

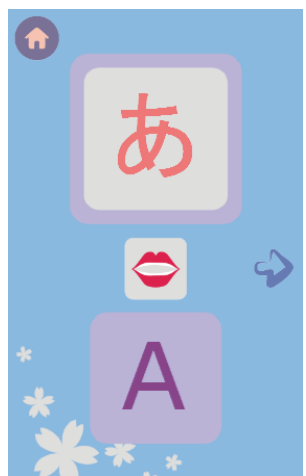

Gambar 19. Prototype Desain Bagian Pembelajaran Level 1

Pada gambar 19 ini merupakan bagian pembelajaran pada level 1, pada proses pembelajaran ini terdapat 3 tombol. Tombol home yang terletak di pojok kiri atas digunakan untuk kembali ke layar sebelumnya, tombol bibir digunakan untuk mendengarkan pelafalan, dan tombol next untuk mengganti ke layar pembelajaran berikutnya. Pada bagian ini 
juga terdapat aksara hiragana (あ) dan romaji (A). Pada bagian ini aplikasi menggunakan font Verdana pada bagian romaji, dan menggunakan font dari Japan Microsoft IME pada bagian hiragana.

e. Prototype Desain Bagian Pembelajaran Level 2

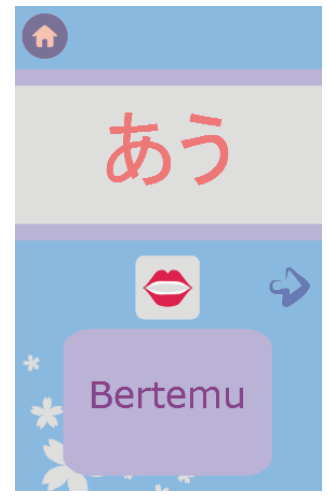

Gambar 20. Prototype Desain Bagian Pembelajaran Level 2

Pada gambar 20 adalah bagian pembelajaran pada level 2 . Pada bagian ini tidak terdapat perbedaan yang jauh dengan bagian pembelajaran pada level 1 , hanya terdapat perbedaan pada panjang area penulisan hiragana dan romaji saja, dikarenakan proses pembelajaran sudah mencapai penggabungan huruf vokal dan konsonan menjadi sebuah kata sederhana. Pada bagian pembelajaran ini juga terdapat tombol pelafalan yang dapat mengeluarkan suara pelafalan dalam bahasa Jepang, suara pelafalan tersebut didapat dari Tanos Grammar Plus pada level ini pelafalan yang digunakan adalah pelafalan berupa suara laki-laki yang memberikan pelafalan huruf vokal dan konsonan.

\section{f. Prototype Desain Bagian Pembelajaran Level 3}

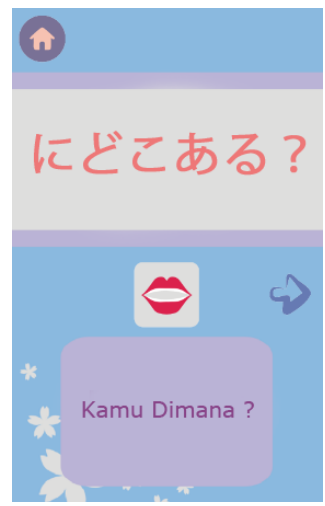

Gambar 21. Prototype Desain Bagian Pembelajaran Level 3

Pada gambar 21 adalah bagian pembelajaran pada level 2. Pada bagian ini tidak terdapat perbedaan yang jauh dengan bagian pembelajaran pada level 2 , hanya terdapat perbedaan pada panjang area penulisan hiragana dan romaji saja, dikarenakan proses pembelajaran sudah mencapai penggabungan kata-kata pada level 2 menjadi sebuah kalimat sederhana. Pada level ini juga terdapat bagian pelafalan yang didapat dari Tanos Grammar Plus, perbedaan terdapat pada suara pelafalan yang digunakan adalah suara perempuan sebagai salah satu variasi dalam aplikasi pembelajaran bahasa Jepang untuk pemula ini.

\section{g. Prototype Desain Menu Level Kuis}

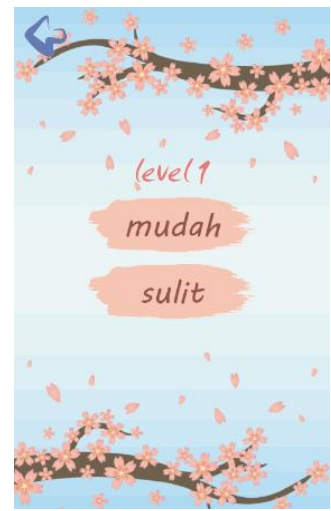

Gambar 22. Prototype Desain Menu Level Kuis

Pada gambar 22 ini merupakan bagian lanjutan dari tombol kuis pada menu pilihan (gambar 17), sebelum pengguna masuk ke bagian kuis pengguna diberikan 2 pilihan yaitu mudah dan sulit. Kedua pilihan tersebut membedakan jumlah soal yang akan diberikan pada bagian kuis. Pada pilihan menu mudah nantinya pengguna akan dihadapkan dengan 10 soal yang diberikan secara random dari daftar huruf, kata, atau kalimat sesuai dengan level pembelajaran yang telah dilewati. Pada halaman ini tombol yang tersedia menggunakan font MV Boli dengan ukuran menyesuaikan resolusi tombol begitu pula pengunaan font pada penanda level.

h. Prototype Desain Bagian Kuis Level 1

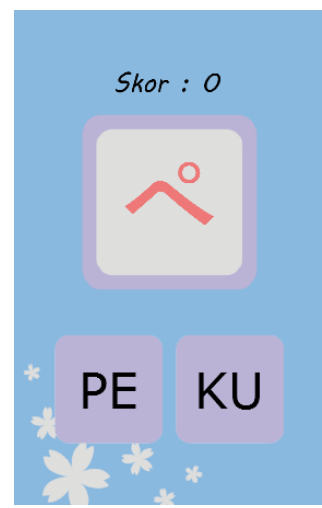

Gambar 23. Prototype Desain Bagian Kuis Level 1

Pada gambar 23 adalah desain dari bagian kuis pada level 1, pada level ini memberikan pengujian terhadap pembelajaran pada level 1 mengenai huruf vokal dan huruf konsonan. Pada bagian ini dibagi menjadi 4 bagian. Bagian pertama adalah bagian soal, soal yang diberikan bisa berupa aksara hiragana maupun berupa romaji, bagian kedua adalah 2 tombol pilihan jawaban. 2 tombol pilihan jawaban tersebut 
digunakan untuk menjawab pertanyaan berdasarkan soal yang ditunjukkan, apabila jawaban benar maka tombol akan berubah warna menjadi hijau dan berubah menjadi merah apabila jawaban yang diberikan salah.

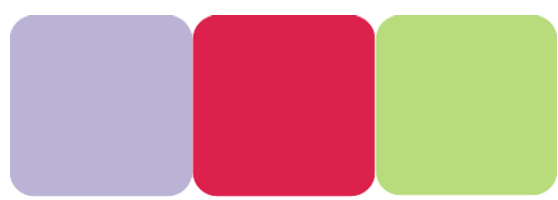

Gambar 24. Desain Prototype Tombol Jawaban Kuis Level 1

i. Prototype Desain Bagian Kuis Level 2

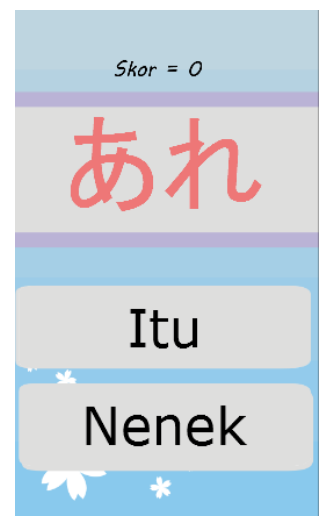

Gambar 25. Prototype Desain Bagian Kuis Level 2

Pada gambar 25 ini adalah bagian kuis pada level 2 soal yang diberikan merupakan kata-kata yang sudah diberikan sebelumnya pada proses pembelajaran pada level 2. Pada bagian kuis level 2 ini juga dilengkapi dengan 2 tombol pilihan jawaban yang akan berubah warna tergantung jawaban yang diberikan benar atau salah seperti pada kuis pada level 1 .

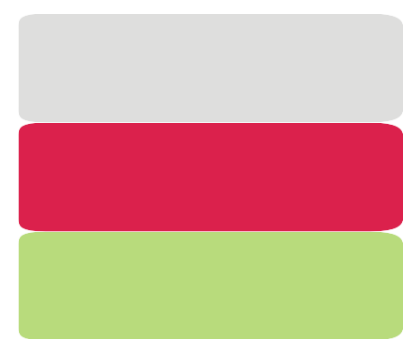

Gambar 26. Prototype Desain Tombol Jawaban Kuis Level 2

j. $\quad$ Prototype Desain Bagian Kuis Level 3

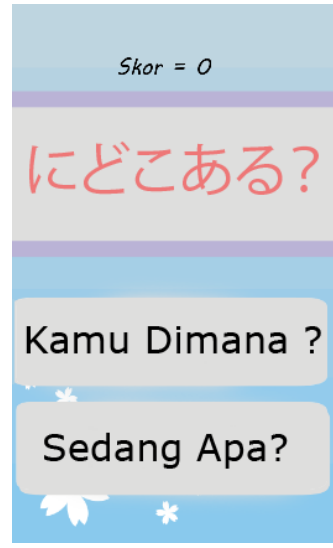

Gambar 27. Prototype Desain Bagian Kuis Level 3

Pada gambar 27 ini adalah bagian kuis pada level 3. Soal yang diberikan merupakan kata-kata yang sudah diberikan sebelumnya pada proses pembelajaran pada level 3. Pada bagian kuis level 3 ini juga dilengkapi dengan 2 tombol pilihan jawaban yang akan berubah warna tergantung jawaban yang diberikan benar atau salah seperti pada kuis pada gambar 3.25. dan dilengkapi dengan suara pelafalan dari soal yang diberikan. Pada bagian ini menggunakan font Verdana pada bagian romaji, dan menggunakan font dari Japan Microsoft IME pada bagian hiragana.

k. Prototype Desain Bagian Layar Skor

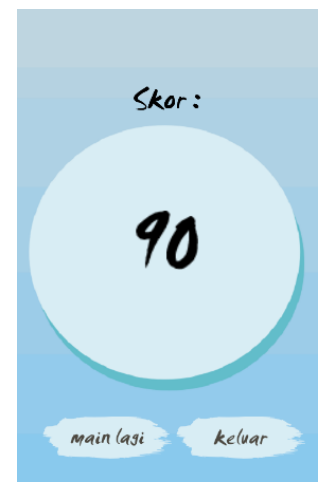

Gambar 28. Prototype Desain Bagian Layar Skor

Pada gambar 28 ini adalah bagian skor yang muncul setiap kali pengguna telah menyelesaikan soal terakhir dari kuis pada level yang telah dipilih. Pada bagian ini terdapat 2 tombol yaitu tombol main lagi dan tombol keluar, tombol main lagi digunakan untuk kembali bermain lagi pada level yang telah dipilih tersebut. Sedangkan tombol keluar digunakan untuk kembali kebagian menu pilihan level (gambar 17.). pada halaman ini font yang digunakan adalah font MV Boli untuk tombol dan untuk teks skor sendiri menggunakan font Smudger.

\section{Prototype Desain Bagian Menu Setting}




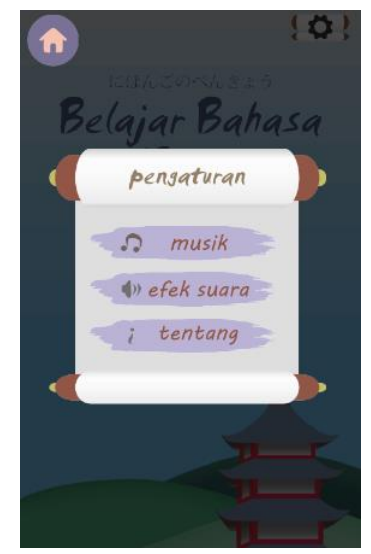

Gambar 29. Prototype Desain Bagian Menu Setting

Pada gambar 29 merupakan bagian yang ditunjukkan apabila tombol setting pada bagian menu utama (gambar 16) ditekan. Pada bagian ini memiliki 4 tombol, tombol pertama adalah tombol home yang terletak pada pojok kiri atas digunakan untuk kembali ke menu utama. Tombol kedua adaah tombol musik digunakan untuk mengatur musik latar apakah dimainkan atau tidak pada saat aplikasi dibuka saat itu, tombol ketiga adalah tombol efek suara yang digunakan untuk mengatur efek suara apakah menyala atau tidak. Efek suara disini adalah suara yang dikeluarkan pada saat tombol pelafalan pada bagian pembelajaran ditekan.

m. Prototype Desain Bagian Layar Tentang (Credit)

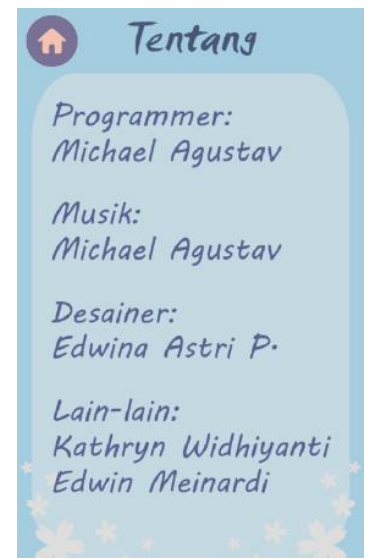

Gambar 30. Prototype Desain Bagian Layar Tentang (Credit)

Pada gambar 30 merupakan bagian yang ditunjukkan apabila tombol tentang ditekan pada bagian setting (gambar 3.28.). Pada bagian ini berisi tentang informasi pembuat aplikasi pembelajaran bahasa Jepang untuk pemula.

\section{i. Evaluasi Desain Prototype Ketiga (Dynamic Design Prototype)}

Berdasarkan tahapan UCD yang telah dilewati, ketiga pengguna sudah menyetujui prototype desain yang akan digunakan pada pembuatan aplikasi pembelajaran bahasa Jepang untuk pemula. Pengguna juga telah menyetujui tentang penggunaan background music (BGM) dan sound effect (SFX) yang telah diujikan sebelumnya.

\section{H. Uji Coba \\ a) Completing a transaction}

Pada sub bab ini penulis akan menggunakan dua metode dari usability testing yang telah disebutkan pada bab dua. Pada bagian ini penulis melakukan pengujian dengan menggunakan metode yang pertama yaitu completing a transaction, disini penulis akan memberikan beberapa skenario kepada pengguna dalam menggunakan aplikasi pembelajaran bahasa Jepang untuk pemula ini.

Pada tahap ini penulis mengujikan aplikasi pembelajaran bahasa Jepang untuk pemula yang telah dibuat kepada 20 orang pengguna. Pengujian yang dilakukan terhadap pengguna yaitu mengujikan aplikasi yang telah dibuat dengan beberapa skenario yang harus diselesaikan. Kemudian dari hasil pengujian yang telah dilakukan, penulis mengambil kesimpulan dari hasil perhitungan persentase seberapa banyak pengguna yang telah menggunakan aplikasi pembelajaran bahasa Jepang untuk pemula ini sesuai dengan skenario yang telah disediakan.

Menggunakan skenario yang telah disediakan di atas dilakukan pengujian terhadap 20 orang pengguna dengan karakterisik yang sama yaitu pelajar SMA dan tidak memiliki kemampuan berbahasa Jepang sama sekali. Dengan pengujian terhadap 20 orang pengguna tadi, penulis telah melakukan perhitungan untuk mengambil berapa banyak pengguna yang telah menyelesaikan skenario yang telah diberikan dengan benar. Hasil perhitungan tersebut dapat dilihat pada tabel berikut:

Tabel 3. Tabel Hasil Perhitungan Skenario Pengujian

\begin{tabular}{|c|c|c|}
\hline No & Skenario & Persentase \\
\hline 1. & Masuk kebagian Pembelajaran & $80 \%$ \\
\hline 2. & Masuk kebagian Kuis & $80 \%$ \\
\hline 3. & Masuk kebagian setting & $100 \%$ \\
\hline 4. & Mematikan BGM & $100 \%$ \\
\hline 5. & $\begin{array}{l}\text { Lanjut ke halaman pembelajaran } \\
\text { berikutnya }\end{array}$ & $90 \%$ \\
\hline 6. & $\begin{array}{l}\text { Kembali ke Menu Awal dari Menu } \\
\text { Level }\end{array}$ & $90 \%$ \\
\hline 7. & $\begin{array}{l}\text { Kembali ke Menu pilihan level dari } \\
\text { menu pilihan pembelajaran atau kuis }\end{array}$ & $100 \%$ \\
\hline 8. & $\begin{array}{l}\text { Melewati bagian tutorial } \\
\text { pembelajaran yang telah disediakan }\end{array}$ & $100 \%$ \\
\hline 9. & $\begin{array}{l}\text { Keluar dari bagian pembelajaran ke } \\
\text { bagian menu pilihan level }\end{array}$ & $90 \%$ \\
\hline 10. & Memilih pilihan mudah atau sulit & $100 \%$ \\
\hline 11. & $\begin{array}{l}\text { Melewati bagian tutorial kuis yang } \\
\text { telah disediakan }\end{array}$ & $100 \%$ \\
\hline 12. & Menjawab pertanyaan kuis & $100 \%$ \\
\hline 13. & $\begin{array}{l}\text { Masuk ke halaman akhir } \\
\text { pembelajaran }\end{array}$ & $70 \%$ \\
\hline
\end{tabular}


Hasil perhitungan di atas didapatkan dengan menggunakan rumus berikut ini:

\section{Jumlah Pengguna Menjawab Sesuai Jumlah Pengguna}

Berdasarkan hasil pengujian yang telah dihitung, dapat disimpulkan bahwa pengguna sudah dapat memahami fitur dan tombol yang telah disediakan pada aplikasi pembelajaran bahasa Jepang untuk pemula. Pada proses pengujian pada soal ke tiga belas terjadi kesalahan pada beberapa pengguna diakibatkan pengguna salah menggunakan tombol skip yang telah disediakan pada bagian pembelajaran dengan tombol next. Maka berdasarkan hasil yang telah didapatkan penulis juga mengambil kesimpulan bahwa skenario yang dianggap sukses adalah skenario yang mendapatkan nilai persentase $>=80 \%$. Berdasarkan hasil dari tabel 3. maka penulis menyimpulkan bahwa skenario yang telah diujikan telah mendapatkan $92.3 \%$ tingkat keberhasilan, persentase tersebut didapatkan dari rumus :

$$
\frac{\text { Jumlah Skenario Berhasil }}{\text { Jumlah Soal Skenario }} \times 100 \%
$$

\section{b) Completing a transaction}

Kemudian penulis melakukan pengujian dengan metode yang kedua yaitu evaluating the impact of subtle changes. Disini penulis akan memberikan beberapa pertanyaan yang telah disediakan, pertanyaan tersebut dibedakan menjadi dua kategori yaitu pertanyaan yang akan dijawab sebelum pengguna menggunakan aplikasi pembelajaran bahasa Jepang untuk pemula dan kategori yang kedua adalah pertanyaan yang di jawab setelah menggunakan aplikasi pembelajaran bahasa Jepang untuk pemula.

Pertanyaan yang diberikan merupakan pertanyaan pada bagian pembelajaran pada level 1 dalam aplikasi pembelajaran bahasa Jepang untuk pemula yang telah dibuat, langkah pertama penulis mengujikan pertanyaan seperti pada kuis level 1. Setelah penulis mengujikan pertanyaan yang telah disediakan kepada pengguna dalam keadaan pengguna belum pernah menggunakan aplikasi pembelajaran yang telah dibuat, kemudian dari hasil pengujian langkah pertama ini disimpulkan seperti berikut:

Tabel 4. Tabel Persentase Pengujian Langkah Pertama

\begin{tabular}{cc}
\hline No Soal. & Persentase \\
\hline 1. & $20 \%$ \\
\hline 2. & $60 \%$ \\
\hline 3. & $50 \%$ \\
\hline 4. & $40 \%$ \\
\hline 5. & $20 \%$ \\
\hline 6. & $30 \%$ \\
\hline 7. & $30 \%$ \\
\hline 8. & $50 \%$ \\
\hline 9. & $40 \%$ \\
\hline 10. & $60 \%$ \\
\hline
\end{tabular}

Dapat dilihat dari tabel hasil persentase pengujian langkah pertama yang dilakukan kepada 20 orang bahwa pengguna benar-benar tidak memiliki pengetahuan mengenai bahasa Jepang. Perhitungan persentase tersebut didapat dari rumus berikut :

\section{$\underline{\text { Jumlah Pengguna Menjawab Benar }} \times 100 \%$ Jumlah Pengguna}

Kemudian setelah dilakukan perhitungan terhadap hasil pengujian dari langkah pertama, penulis mengujikan aplikasi pembelajaran bahasa Jepang untuk pemula yang telah dibuat kepada pengguna yang telah berpartisipasi dalam pengujian langkah pertama tadi.

Setelah pengguna menggunakan aplikasi pembelajaran bahasa Jepang untuk pemula, kemudian dilakukan pengujian langkah kedua yaitu pengujian dengan menjawab pertanyaan yang telah diujikan. Pertanyaan yang diberikan pada langkah ini adalah pertanyaan yang sama dengan pertanyaan yang telah diberikan pada langkah sebelumnya. Berikut adalah perhitungan persentase dari pengujian langkah kedua:

Tabel 5. Tabel Persentase Pengujian Langkah Kedua

\begin{tabular}{lc}
\hline No. & Persentase \\
\hline 1. & $80 \%$ \\
\hline 2. & $80 \%$ \\
\hline 3. & $100 \%$ \\
\hline 4. & $90 \%$ \\
\hline 5. & $80 \%$ \\
\hline 6. & $100 \%$ \\
\hline 7. & $90 \%$ \\
\hline 8. & $80 \%$ \\
\hline 9. & $80 \%$ \\
\hline 10. & $90 \%$ \\
\hline
\end{tabular}

Berdasarkan hasil tersebut dapat dilihat bahwa terjadi perbedaan persentase kepada pengguna, sebagai contoh pada soal nomor 5 dan nomor 6 . Setelah menggunakan aplikasi pembelajaran bahasa Jepang yang telah dibuat, terdapat 4 orang pengguna menjawab dengan benar pada soal nomor 5 pada langkah pertama. Kemudian pada langkah kedua pengguna yang menjawab benar meningkat menjadi 16 orang. Dengan menggunakan hasil dari persentase pada langkah kedua, penulis kemudian menarik kesimpulan sampai sejauh mana pengguna dapat memahami materi yang diberikan pada aplikasi pembelajaran bahasa Jepang untuk pemula ini. Dengan melihat persentase dari pengguna yang menjawab benar di atas $80 \%$, dapat disimpulkan bahwa aplikasi pembelajaran ini sangat membantu bagi pengguna dalam mempelajari bahasa Jepang.

\section{KESIMPULAN DAN SARAN}

Bab ini penulis akan membahas beberapa kesimpulan yang dapat diambil. juga terdapat saran-saran yang 
bermanfaat dan membangun dalam pengembangan aplikasi lebih lanjut.

\section{A. Kesimpulan}

Kesimpulan yang dapat diambil dari penelitian pembuatan aplikasi pembelajaran bahasa Jepang untuk pemula berbasis android antara lain:

- Aplikasi pembelajaran bahasa Jepang untuk pemula berbasis Android dikembangkan menggunakan metode user centered design dilakukan dengan beberapa pengujian. Pengujian tersebut dilakukan kepada beberapa pengguna sebagai koresponden. Pengujian yang dilakukan adalah pengujian desain terhadap tiga pengguna sebagai narasumber dengan tiga karakteristik yaitu pengguna dengan kemampua berbahasa Jepang fasih, pengguna dengan kemampuan berbahasa Jepang menengah, dan pengguna yang tidak memiliki kemampuan berbahasa Jepang sama sekali. Kemudian tahap berikutnya adalah pengujian terhadap fitur-fitur yang telah disediakan pada aplikasi pembelajaran bahasa Jepang untuk pemula.

- Aplikasi pembelajaran bahasa Jepang untuk pemula ini dilengkapi dengan bagian pembelajaran untuk mengenalkan pengguna kepada hiragana dasar dan dilengkapi dengan fitur kuis yang digunakan untuk menguji sejauh mana pemahaman pengguna. Aplikasi ini telah diuji menggunakan dua metode yang diambil dari sepuluh metode pada usability testing. Metode yang pertama adalah metode completing a transaction dimana dapat disimpulkan bahwa 92,3\% dari sistem navigasi dan fitur yang ada pada aplikasi pembelajaran ini telah dipahami oleh pengguna. Kemudian dilanjutkan dengan pengujian metode kedua yaitu evaluating the impact of subtle change. Pada pengujian tahap ini diperoleh hasil $100 \%$ tingkat pencapaian keberhasilan aplikasi ini dalam membantu pengguna mempelajari bahasa Jepang.

B. Saran

Saran untuk pengembangan aplikasi pembelajaran bahasa Jepang untuk pemula lebih lanjut adalah:

1. Perlu ditambahkan kosakata yang lebih sering digunakan sehari-hari.

2. Penggunaan suara pelafalan yang lebih jernih.

3. Perlu ditambahkan fungsi pengaturan suara pada saat pembelajaran maupun kuis sedang berlangsung.

4. Tingkat kesulitan kuis disetarakan dengan uji N5.

\section{REFERENSI}

[1] Proboyekti, U. (2008). User Interface Design.

[2] Meiler, R. (2009). Profesional Android Application Development, Canada: Wiley Publishing.

[3] Slavin, R. E. (2010). Cooperative Learning: Teori, Riset, dan Praktik, Bandung: Nusamedia.

[4] Suhendar, A. (2002). Visual Modelling Menggunakan UML Dan Rational Rose, Bandung: Informatika. 